\title{
An Estimate of the Shadow Wage Rate in Pakistan ${ }^{1}$
}

\author{
Shahrukh Rafi KhaN*
}

\section{Introduction}

In the past few years, increasing attention has been given to the methods by which investments in developing countries should be appraised. Benefitcost analyses, based on market prices and costs, do not indicate whether an investment would be profitable from a social point of view. The methods of project evaluation developed in the past decade suggest ways in which private costs and benefits can be adjusted to reflect positive or negative externalities and to eliminate the effects of distorting taxes and subsidies which influence private decisions but which do not affect an investment's fundamental economic value. One item in an investment's cost for which the market value is widely believed to be unrepresentative of its social value is labour. Much of development theory has been built around the notion that labour is misallocated, largely because it is mis-priced. Urban labour commands a wage above its equilibrium price because of the effects of unions, minimum wage legislation and other institutional_rigidities. For institutional reasons as well, rural labour is paid a wage which is in excess of its marginal contribution to agricultural output. Determining the social opportunity cost of labour is consequently. essential to the proper evaluation of investment in both rural and urban areas.

This paper examines some of the problems of determining the social opportunity cost of labour-also referred to as labour's shadow wage rate (SWR) --in Pakistan and provides an estimate based on the available information. The approach adopted in this paper is the same as outlined by Little and Mirrlees [8]. The first section surveys the logic behind the Little-Mirrlees approach while the second section provides an estimate of the shadow wage rate for unskilled labour in Pakistan during 1970-71 along with a critical discussion of the data and assumptions used in obtaining them.

*The author is Research Economist at the Pakistan Institute of Development Economics, The study was suggested by Stephen Guisinger, Research Adviser to the Institute, and the author has benefited from his advice and guidance at every stage. John Hansen of the I.B.R.D. read an earlier draft and made several useful suggestions. The author is also thankful to A.R. Kemal for some useful comments, to Jerry Eckert for providing some data and to Bilquees Naqvi for computational assistance.

${ }^{2}$ This study is part of a broader research effort by the Pakistan Institute of Development Economics to estimate the shadow price for the principal domestic factors e.g., land, capital, electricity, etc., that figure importantly in a project's capital and operating costs. 


\section{Factors Affecting the Shadow Wage Rate}

The shadow wage rate depends not only on the cost to society of withdrawing a worker from one sector of the economy but also on the additional costs to society which his re-employment in another sector may entail. As Little and Mirrlees consider the case of a worker migrating from the rural sector to the urban sector, these two types of costs are measured by the loss of agricultural output, denoted by $m$, resulting from the removal of one labourer and by the net increase in the consumption of goods and services which results when the worker is hired in the higher paid urban sector. The measure of this net increase in consumption is represented by $c-m$, where $c$ is average consumption expenditures of an urban worker. ${ }^{2}$ It may seem paradoxical to regard the increased consumption of workers as a cost. In fact, Little and Mirrlees do acknowledge that this increased consumption does have a social value which must be reflected in the SWR, but recognition of the simultaneous social cost of this increased consumption is an intergral part of the Little-Mirrlees approach.

The social cost of consumption arises because developing countries, almost by definition, are capital-scarce countries. In view of this capital scarcity any increase in consumption with a given level of total income corresponds to a decrease in investment, and hence a decrease in future consumption. This is because the present value of the future stream of consumption benefits generated by one rupee of investment is greater than the value derived from the same rupee consumed now. Thus, the social gains in immediate consumption are generally more than offset by the social losses of future consumption foregone. Using the terms defined previously, the cost of transferring labour from the rural to the urban sector is $m+(c-m)$, i.e. the social cost of output foregone in the agricultural sector plus the social cost of investment foregone due to increase in consumption.

From this social cost should, however, be subtracted the social value of the present consumption enjoyed by the transferred worker, namely $c-m$ again; i.e. if society valued consumption and investment equally then the social value of this increased consumption would be the same as the social cost of investment foregone due to the increase in consumption. But, as noted above, society must place a lower value on this consumption compared to an equivalent value committed to investment because of the decrease in future consumption it will generate. Thus, Little and Mirrlees deflate this value of consumption by a factor designated as $1 / s$, where $s$ is a ratio greater than one and reflects the social value of investment expressed in terms of consumption. In other words if $s=2$, the implication is that the present value of future stream of consumption benefits generated by one rupee of investment is twice as valuable from a social point of view as the one rupee of immediate consumpion. Thus the total cost of employing another man is:

$$
\mathrm{SWR}=m+(c-m)-1 / s(c-m)
$$

Why the net increase is measured by $c-m$ is explained in detail in [9, pp. 158-159]. Note also that, following the logic employed through-out [9], both $c$ and $m$ are measured at border prices-i.e. the prices of goods and services which would obtain if the economy were operated under free trade conditions. For a futher justification of the use of border prices, see [7, pp. 143-148].

Transport cost of moving from country to town and urban overheads have beon assumed negligible. 
Obviously, if a government has already achieved the socially desired level of saving through monetary and fiscal policies, then a premium need no longer be placed on saving relative to consumption and $s$ would equal one. In such a case the SWR would be simply equal to $m$, the marginal product of labour in the rural sector. Little and Mirrlees argue throughout that for most poor countries $s$ is likely to be significantly greater than one-even as much as 3.0 in some cases, indicating that the social value of present consumption in such cases is only one-third of its nominal value to workers.

\section{Estimation of $m:$ Who is the Marginal Worker?}

Little and Mirrlees suggest three methods for computing $m$. The preferred method is to estimate $m$ directly by computing the marginal product of labour from a statistically estimated production function for the agricultural sector. The use of this technique, however, requires a vast amount of information since production functions differ from crop to crop. Also, a very large number of observations would be needed to average out variations in land and weather conditions in different parts of the country and the varying degrees of skills among workers and farm managers. The second and, perhaps, least desirable alternative is to simply estimate the average productivity of labour in agriculture and then assume that marginal productivity of labour is roughly half of the average product. This approach, however, is no more than a rule of thumb and should be used only when data are lacking. The third approach, and the one adopted in this study, is to compute $m$ by calculating labour's marginal revenue product implied by the average number of days worked by rural labour and their market wage.

In the light of the abundant empirical evidence available on the rationality of farmers, we can assume that rural labour is hired for only as many days as necessary, and paid only the minimum market wage rate consistent with profit maximisation. The first step, then, in estimating labour's marginal revenue product is to calculate the number of days in the year for which labour in the agricultural sector is fully employed in different activities. Multiplying the total number of days with the wage rate on these days we get an estimate of the marginal revenue product of a man-year in agriculture. The logic behind this is that at certain peak seasons of the year (e.g. at harvest time) the demand for labour can absorb all those wanting to work. In this case the neo-classical postulate of labour wage equalling its marginal revenue product holds. At other times of the year, there may be men wanting to work but unable to find employment. The marginal product of unemployed labour is, of course, zero. However, the average marginal product of labour for the year (days worked wage plus days not worked 0 ) is a measure of the contribution of the marginal worker to output in the rural sector.

The estimation of the SWR is based on the social cost of removing a typical worker from the rural sector and re-employing him in the urban sector. Since our study is primarily concerned with the shadow price of unskilled labour, it is necessary to establish from which groupt urban migrants are drawn.

'The various groups in the rural sector are farmers, tenants, shopkeepers, artisans and landless labour (temporary and permanent). Farmers include only landowners and ownercum-tenants. 
Farmers are unlikely candidates for unskilled jobs in the urban sector since most of those who migrate either do so for education or, being already educated, do not like to accept unskilled jobs. Artisans reveal a high propensity to continue their village occupations in urban areas. This leaves tenants, permanently employed farm labourers, and temporarily employed labour. A filtering down process may occur: as a result of a tenant leaving for an unskilled job in the urban sector, a permanent landless labourer takes over the tenancy, and, in turn, a temporary landless labour is hired to take his place. Thus, the relevant social opportunity cost, or $m$, is the marginal product (or product foregones) of the worker at the end of the chain, namely, temporary landless labour.

The procedure followed to estimate $m^{6}$ in domestic prices was first to identify the activities for which temporary landless labour was hired. The average number of mandays worked by temporary landless labour was 136 per year of which 54 days were spent doing non-agricultural work, such as construction and loading. Thus, the next step was to estimate how the remaining 82 days were distributed (Appendix Table I-IV, column 5) among the various agricultural activities for which temporary landless labour was employed. Finally, the product of the number of days in both the agricultural and nonagricultural activities with the appropriate wage rate was summed up to obtain the value of $m$ in domestic prices.

The $m$ in domestic prices was revalued in terms of border prices by using the following procedure:

$$
\left(\mathbf{M P P}_{\mathbf{L}} \cdot \mathbf{P}_{\mathrm{d}}\right) \frac{\mathbf{P}_{\mathrm{w}}}{\mathbf{P}_{\mathbf{d}}}={ }^{\prime} \mathbf{M P P}_{\mathrm{L}} \cdot \mathbf{P}_{\mathbf{W}}
$$

Since the domestic value of $m$ is equal to the domestic price of goods produced by labour multiplied by the marginal physical product of labour, $m$ at border prices can be estimated simply through multiplication of ' $m$ ' at domestic prices by a factor, $\frac{\mathbf{P}_{\mathbf{w}}}{\mathbf{P}_{\mathbf{d}}}$, where $\mathbf{P}_{\mathbf{w}}$ and $\mathbf{P}_{\mathbf{d}}$ are, respectively, the average border prices and domestic prices of agricultural goods. Table 1 gives the domestic and border price for major agricultural crops.

Labour's annual marginal revenue product at border prices is the weighted average of the marginal revenue products in the separate activities engaged in during the year. As these activities vary from district to district according to the cropping pattern, $m$, too, differs from region to region. Any structural change affecting the variables used in estimating $m$ by this technique, such as the total number of mandays worked in a year by landless labour, will obviously produce different values for $m$.

For instance, tractorisation may be a factor which alters the mandays worked in a year by landless labour. Research conducted to ascertain the impact of tractorisation on the rural labour market suggests that only the functions performed by family workers and permanently hired workers are 
Domestic and Border Prices" for Major Agricultural Crops

(Rupees)

Crop Units Domestic Price

Border Price

$\begin{array}{llrc}\text { Wheat } & \text { Maund (82.29 lbs.) } & 19.33 & 27.00 \\ \text { Cotton } & \text { Bale (392 lbs.) } & 110.22 & 100.82 \\ \text { Sugar cane } & \text { Maund (82.29 lbs.) } & 2.50 & 0.775^{b} \\ \text { Rice } & \text { Maund (82.29.lbs.) } & 37.98 & 39.01\end{array}$
- Domestic prices of wheat and cotton were taken from [13] while the domestic price of
sugarcane was from [15].

The border price of wheat was taken from [15] and the border price of cotton from [13]. Domestic procurement and export prices of basmati rice were also available in [15]. bSugarcane in domestic prices was converted into border prices by estimating the mark-up on
cane price from the following formula:

$$
c^{2}(1+x)+2(1+m)-(1+t)
$$

in which the weighted sum of $x$ mark-up on cane and $m$ mark-up on sugar refining is equal to $t$, the total mark-up, reflected by the tariff rate. The relative weights $c$ and $r$ show the percentage mark-up attributable to cane and refining. The total mark-up on cane was estimated to be $325 \%$.

replaced by tractors. However, having been displaced, the permanently employed labour may enter the market of temporary landless labour causing the average mandays worked per year by the latter to decrease, thereby reducing the value of $m$. Nevertheless, for four districts, based on the existing labouruse patterns of 1970-71 $\mathrm{m}$ has been worked out in the Appendix Tables I to IV and the results are summed up in Table 2.

\section{Table 2}

\section{Labour's Marginal Product \\ ( $m$ by District)}

(Rupees per year)

\begin{tabular}{lcc}
\hline District & $\begin{array}{c}\text { Domestic Prices } \\
(\mathrm{m})\end{array}$ & $\begin{array}{c}\text { Border Prices } \\
(\mathrm{m})\end{array}$ \\
\hline Rahim Yar Khan & 415.05 & 340.05 \\
Sahiwal & 408.88 & 354.23 \\
Lyallpur & 406.91 & 332.45 \\
Gujranwala & 412.36 & 386.96 \\
\hline
\end{tabular}

\section{Estimation of $c$}

Another component in the shadow wage rate formula is $c$, the consumption expenditures of workers valued at border prices. As total expenditures can be divided among individual expenditure categories and the domestic value of these individual items can be converted to border values by the application of the appropriate price ratios, the estimation of $c$ poses no especially difficult problem. The allocation of the typical Pakistani industrial worker's monthly income of Rs. 120.6 among various expenditure categories is shown in 
Table III Col. d, while Column e of the same table gives the value of each expenditure at border prices. The standard procedure of converting the domestic values of importables to their equivalent in border prices is to multiply the domestic value by the ratio of the c.i.f. price (Karachi) to the domestic price of the corresponding commodity. This procedure has been used in Table 3 to convert the domestic prices of items 1-4 (all of which were imported). Items 6 and 7 have been treated differently since they are exported from Pakistan." Normally the ratio of the f.o.b. and current market prices could be used to convert the domestic prices of these items to their value in border price. Since these commodities (items 6 and 7) were exported under the bonus voucher scheme, which amounted to a subsidy on exports, the border prices were lower than domestic prices. The extent by which domestic prices needed to be deflated can be estimated by the formula: $1 / 1+r \cdot p$ where $r$ is the bonus rate and $p$ the bonus premium.

For items 9-10 similar estimates could not be made because these goods are not traded internationally. Instead, their domestic values were converted into accounting values by using the standard conversion factor (SCF), as described by Little and Mirrlees [9, p. 154].

This SCF is the weighted average of the proportions by which the domestic prices (net of purchase or excise tax) of traded goods in Pakistan exceed their border prices. Since the weighted average price differential ${ }^{8}$ was found to be $37.5 \%$ of domestic prices, the average value of these items at border prices is $62.5 \%$ of their value at domestic prices. From Table III it can be seen that the value of consumption in border prices is approximately two-thirds of its domestic value.

\section{Estimation of $s$}

The notation $s$ indicates premium which society places on a rupee's worth of saving (i.e. investment) compared to a rupee's worth of consumption. Whether it is greater than, or equal to, one depends on the relationship between two rates of interest, namely, $i$, the consumption rate of interest, and $r$, the accounting rate of interest. The consumption rate of interest is the rate at which the weight now given to future income falls over time. The accounting rate of interest is the amount by which present income is more valuable than future income or, what is the same thing, the rate at which the weight now given to future investable funds falls over time. The accounting rate of interest can be considered equivalent to the social return on investment that is not committed to consumption. For developing countries, $r$ is normally greater than $i$. However, as long as this holds the economy is not in an optimal situation because the marginal rate of transformation of present into future consumption is greater than the marginal rate of substitution between present and future consumption. Thus, as long as $r$ is greater than $i, s$ is greater than one because saving is more valuable to society than consumption and, therefore, a premium must be attached to it.

If the present level of the growth of economy in Pakistan is maintained or exceeded in the next two or three decades, both $r$ and $i$ are likely to converge

Item 8, rice, is also exported. However, since $91 \%$ of rice exported was Basmati, and only coarse rice is consumed locally, it was treated as a non-tradeable. (Figures relate to 1970-71.)

Estimates of price differentials were from Lewis and Guisinger [8]. 


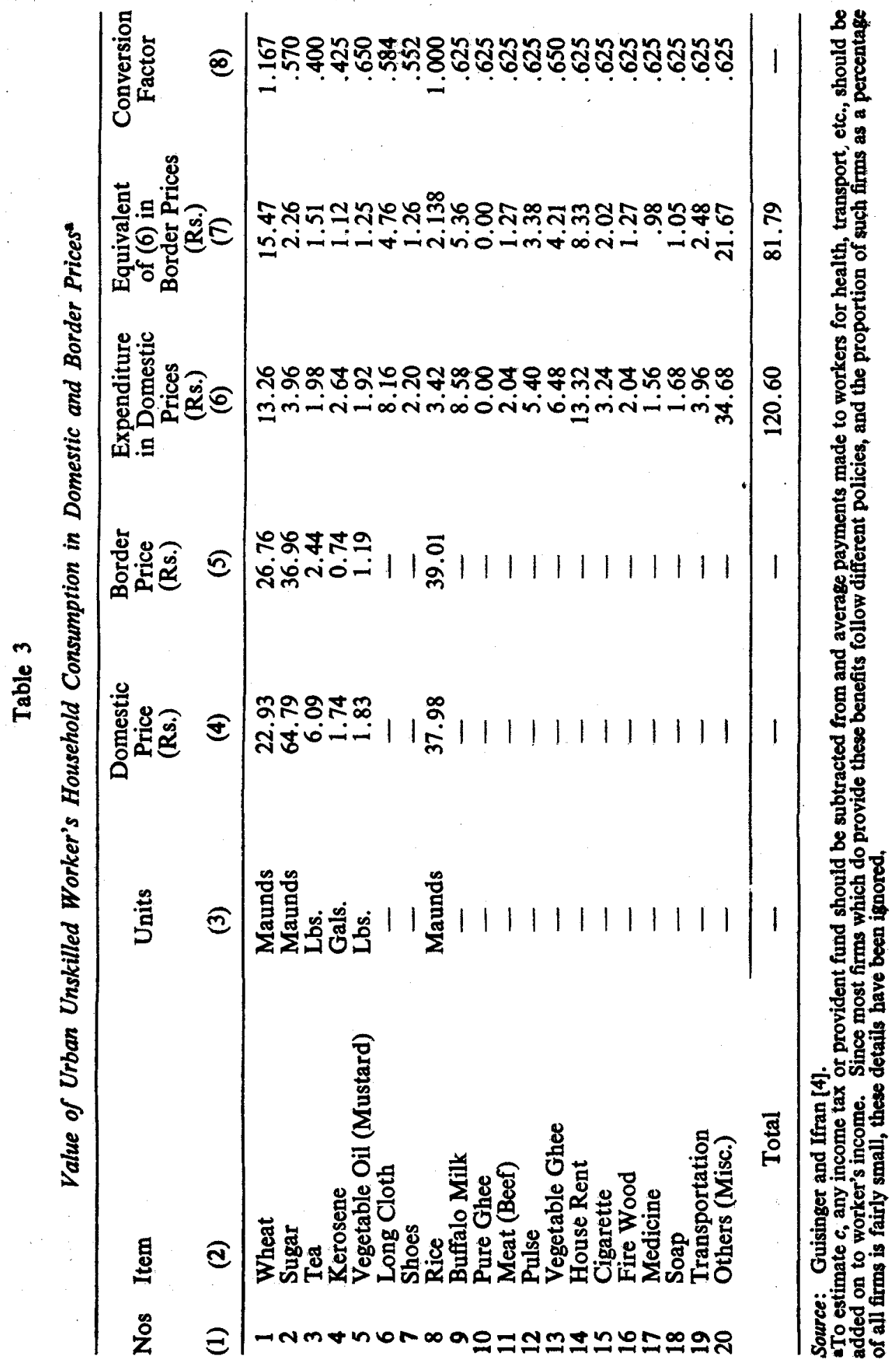


over time. The social return on investment will fall because projects with a high return will already have been undertaken. On the other hand, the consumption rate of interest will fall with the growth of the economy because future consumption will become more valuable in terms of present consumption and will, therefore, need to be discounted by a lesser amount. However, because $r$ will be falling at a faster rate than $i$, the two will converge. The convergence between the two will turn into an equality at some point, call it $T$, in the future. At $T$, society will value consumption and saving equally and, therefore, $s$ will be equal to one. Finally, on the assumption that the divergence between $r$ and $i$ diminishes steadily from now until $T$, the current value of $s$ may be estimated through the following formula ${ }^{10}$ :

$$
s=\left(1+1 / 2\left(r_{i}-i_{i}\right) T\right)
$$

\section{Estimation of $r$}

$r$ is one of the two variables that need to be computed to estimate $s$. Ideally if information about cash flows over time were available for marginal projects, or could be estimated from the formula:

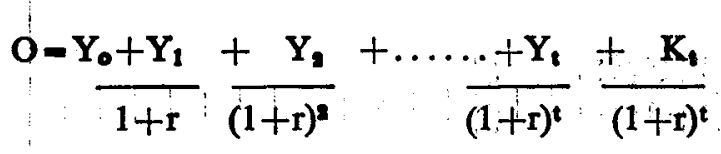

where $Y$ is the net cash flow over time and $K$ is the scrap value of capital after $t$ years (all in border prices). Since this information is not normally available, $r$ has been estimated simply by dividing $Y$ and $K$ at border prices (total capital stock) for all industries listed in the Census of Manufacturing Industries (CMI) [16].1. From the analysis in Appendix Table VII, it can be seen that $r$ varied between 11.5 and 15.5 perc ent.

\section{Estimation of $i$}

The consumption rate of interest is the other variable required in the estimation of $s$. For computing $i$, we have drawn upon the following formula developed by Lal [7, pp. 150-151].

$$
i_{\mathrm{t}}=\left(1+g_{\mathrm{t}}\right)^{-0}-1
$$

where $g_{t}$ is the growth rate of per capita consumption and $e$ the elasticity of social marginal utility of consumption. With the growth of the economy, $g_{t}$ would rise. However, the greater the growth rate of consumption, the less valuable the future consumption in terms of present consumption. Hence to give future consumption less weight, it is discounted by a larger $i$. Growth of per capita consumption was estimated on the assumption that the future rate of growth of per capita consumption will be the same as the rate of growth in the past.

For an excellent description of the changes in $r$ and $i$ overtime for a developing economy, soe Little and Mirrlees [9, pp; 283,86].

${ }^{10}$ From [7, $\left.\mathrm{p}, 179\right]$. In the revised edition of their boaks; the authors have suggested two other ways of estimating s, which are somewhat more complicated:

11This average estimate was resorted to because of practical difficulties involved in identifying the firms "at the margin." 
Table 4 shows an increase in per capita consumption from Rs. 387.4 in 1959-60 to Rs. 568.6 in 1969-70. The estimated compound rate of growth per annum between $1959-60$ and $1969-70$ was $3.7 \%$.

Table 4

\begin{tabular}{cccc}
\hline Year & Population & $\begin{array}{c}\text { Consumption* } \\
\text { (Million Rupees) }\end{array}$ & $\begin{array}{c}\text { Per Capita } \\
\text { Consumption* } \\
\text { (Rs.) }\end{array}$ \\
\hline $1959-60$ & $41,911,150$ & 16236.0 & 387.4 \\
$1969-70$ & $54,144,152$ & 30784.9 & 568.6 \\
\hline
\end{tabular}

Source: Naseem S.M. [11]

At 1959/60 prices.

The elasticity of social marginal utility of consumption has been defined as the ratio of the income elasticity of the demand for food to price elasticity of the demand for food. Bussink [11] has estimated both these elasticities for a variety of food items for West Pakistan. On the basis of these values, $e$ was found to be-1.01 (Appendix Table VI). Inserting the values for $g_{t}$ and $e$ into the formula, we found the consumption rate of interest to be $4 \%$.

\section{The Shadow Wage Rate}

Having obtained estimates of $c, m$ and $s$, we are now in a position to calculate the shadow wage rate (SWR) for unskilled labour. From the foregoing account, it is evident that the value of each of these variables can vary depending on which set of "reasonable" assumptions is employed. The SWR, corresponding to four sets of assumptions, is shown in Table 5.

Table 5 shows that as the economy approaches $T$, the premium on saving falls as is reflected by the drop in $s$ from 2.5 to 2.0 . Consequently, the SWR also falls from 0.50 to 0.45 of the market wage rate (MWR). It can also be seen that if the additional consumption from employing a worker in the urban sector is not considered a social cost (i.e., $s$ is equal to one), the only social cost of transferring a worker is the loss of agricultural output, $m$, and SWR drops to 0.24 of the MWR. Finally, if $m$ is assumed to be zero, implying that the product foregone of unskilled labour in the rural sector is nil, the SWR falls, once again, this time from 0.50 to 0.42 of the MWR.

Variation in $m$ (holding $c$ constant) is assumed in this paper to determine how unskilled labour migrating from these regions should be priced. Thus the greater the variation in $m$ by regions the greater is the variation in the SWR. Although about a $14 \%$ variation was found in $m$ (Table II) this did not cause the SWR to vary significantly. 
Table 5

Components of the Shadow Wage Rate

\begin{tabular}{|c|c|c|c|c|c|}
\hline & Component & & & tions & \\
\hline & & 1 & 2 & 3 & 4 \\
\hline 1) & $\begin{array}{l}\text { Marginal Product (M) } \\
\text { (Rs. per year) }\end{array}$ & 360 & 360 & 360 & 360 \\
\hline 2) & $\begin{array}{l}\text { Comsunption of Urban } \\
\text { Worker (c) } \\
\text { (Rs. per year) }\end{array}$ & 980 & 980 & 980 & 980 \\
\hline 3) & Premium on Saving (S) & 2.5 & 2.0 & 1 & 2.7 \\
\hline 4) & $\begin{array}{l}\text { Rate of Return on } \\
\text { Capital (r) } \\
(\%)\end{array}$ & 16.5 & 15.5 & 18.5 & 16.0 \\
\hline 5) & $\begin{array}{l}\text { Consumption Rate of } \\
\text { Interest (i) } \\
(\%)\end{array}$ & 4 & 4 & 0 & 4 \\
\hline 6) & $\begin{array}{c}\text { Planning Horizon }(\mathrm{T}) \\
\text { (years) }\end{array}$ & 50 & 25 & 0 & 50 \\
\hline 7) & $\begin{array}{l}\text { SHADOW WAGE RATE } \\
\text { (SWR) } \\
\quad \text { (Rs per year) }\end{array}$ & 720 & 648 & 360 & 605 \\
\hline 8) & $\begin{array}{l}\text { MARKET WAGE RATE } \\
\text { (MWR) } \\
\text { (Rs. per year) }\end{array}$ & 1440 & 1440 & 1440 & 1440 \\
\hline 9) & SWR & 0.50 & 0.45 & 0.24 & 0.42 \\
\hline
\end{tabular}




\section{Conclusion}

This study has suggested that the shadow wage rate in Pakistan is approximately one-half of the market wage, and not zero, as it is often assumed to be. If labour is withdrawn from the rural sector and re-employed in the urban sector, agricultural output will decline and the aggregate consumption of society will rise. The loss of production and the loss of potential investment through the increase in consumption are costs to society which a higher marginal productivity of labour in the urban sector must offset if labour is to be efficiently allocated.

The use of the shadow wage, rather than the market wage, in project appraisals may make a substantial difference in determining whether the project is acceptable from an economic point of view. If unskilled labour accounts for a quarter of project costs, shadow pricing the labour component will bring down total project costs by more than 10 per cent. Plainly, the more labour-intensive a project, the more important the application of the shadow wage rate. Three cautionary notes should be sounded, however, about the use of the type of shadow price estimated in this study. First, if projects can be designed to make maximum use of labour during the off-peak seasons in agriculture, then the shadow wage rate would be substantially lower, but will still not be zero because of the consumption effect. Second, the shadow wage rate may differ across geographic regions. No evidence of this was found in four separate regions of the Punjab, but the possibility certainly exists because cropping patterns differ more across than within the provinces. Finally, the relationship between the market and shadow wage may vary over time. Our estimate for 1970-71 may, therefore, be outdated. A survey of labour inputs by crop, especially one focussing on the effects of farm mechanization, would be desirable before these estimates are applied in project evaluation. There is, however, some basis for believing that the ratio between the two wage rates might remain roughly constant: at any rate, for a decade or so. As the date approaches when investment is expected to be at a satisfactory level, the marginal investment project will become relatively more valuable than the consumption they displace, causing the shadow wage rate to fall. On the other hand, an increase in labour productivity in the rural sector due to mechanization would tend to raise the shadow wage rate. The study by Little and Mirrlees [9] suggests that it would not be unreasonable for planners to assume that these two opposing influences cancel each other out. 


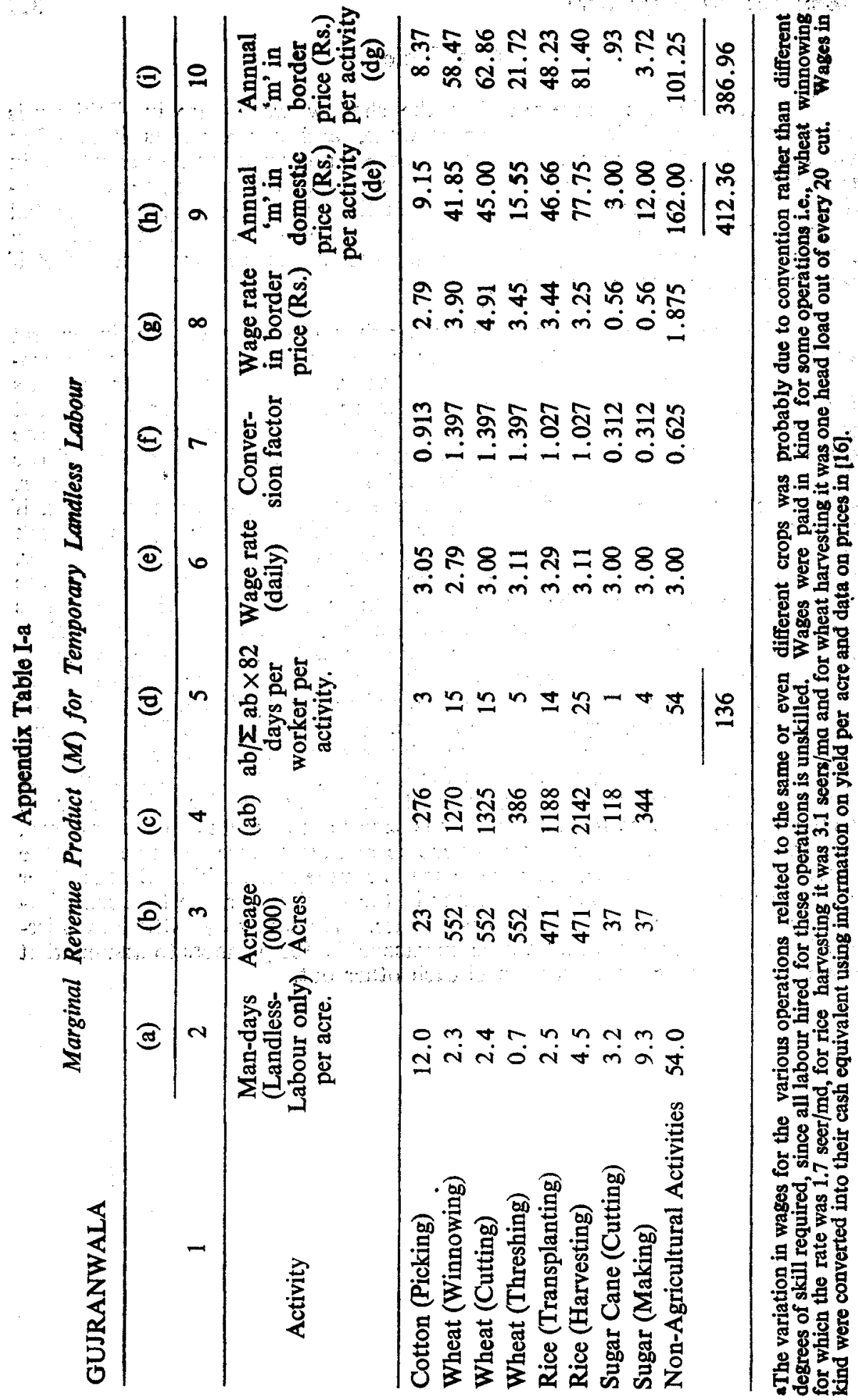




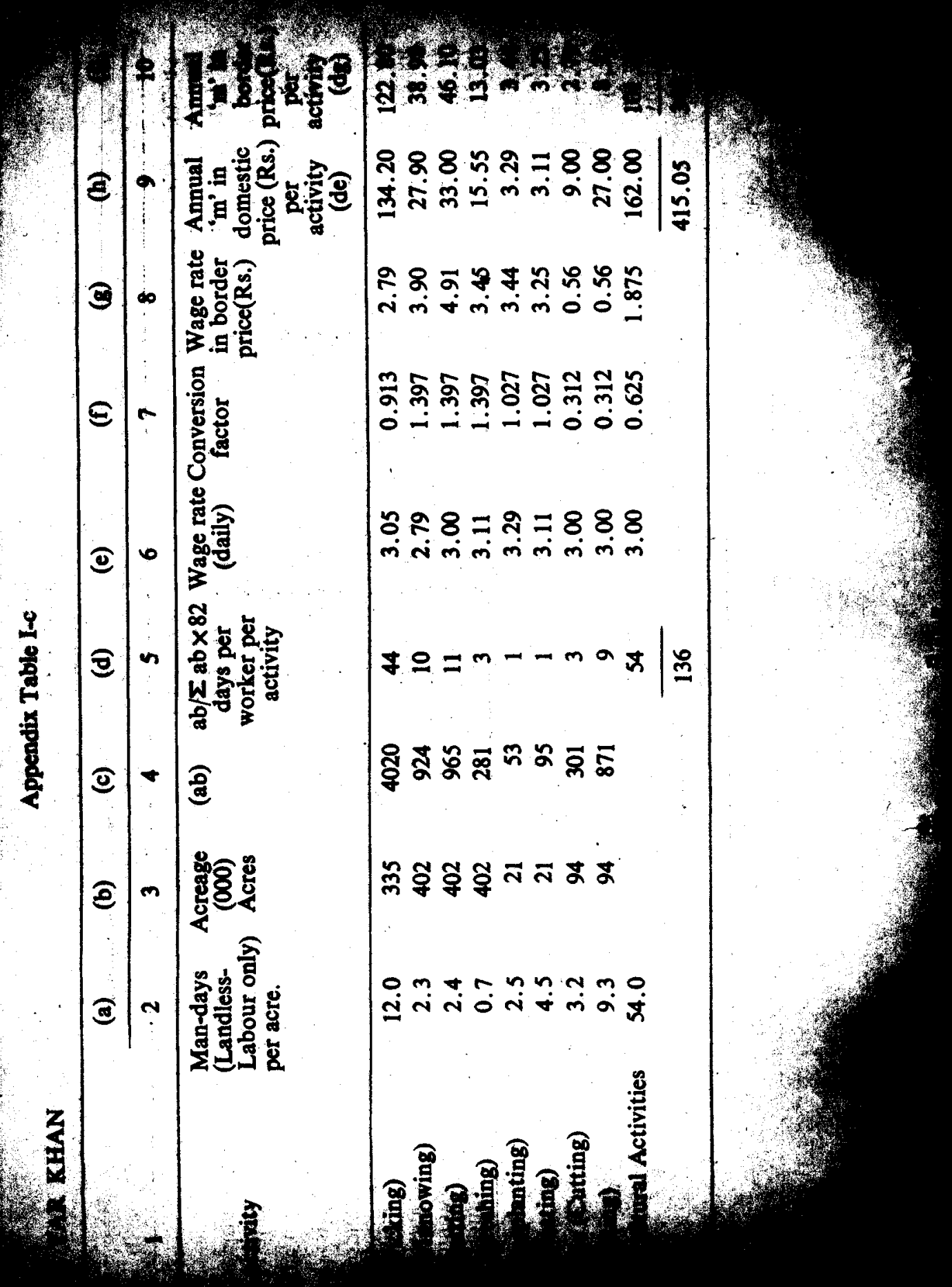




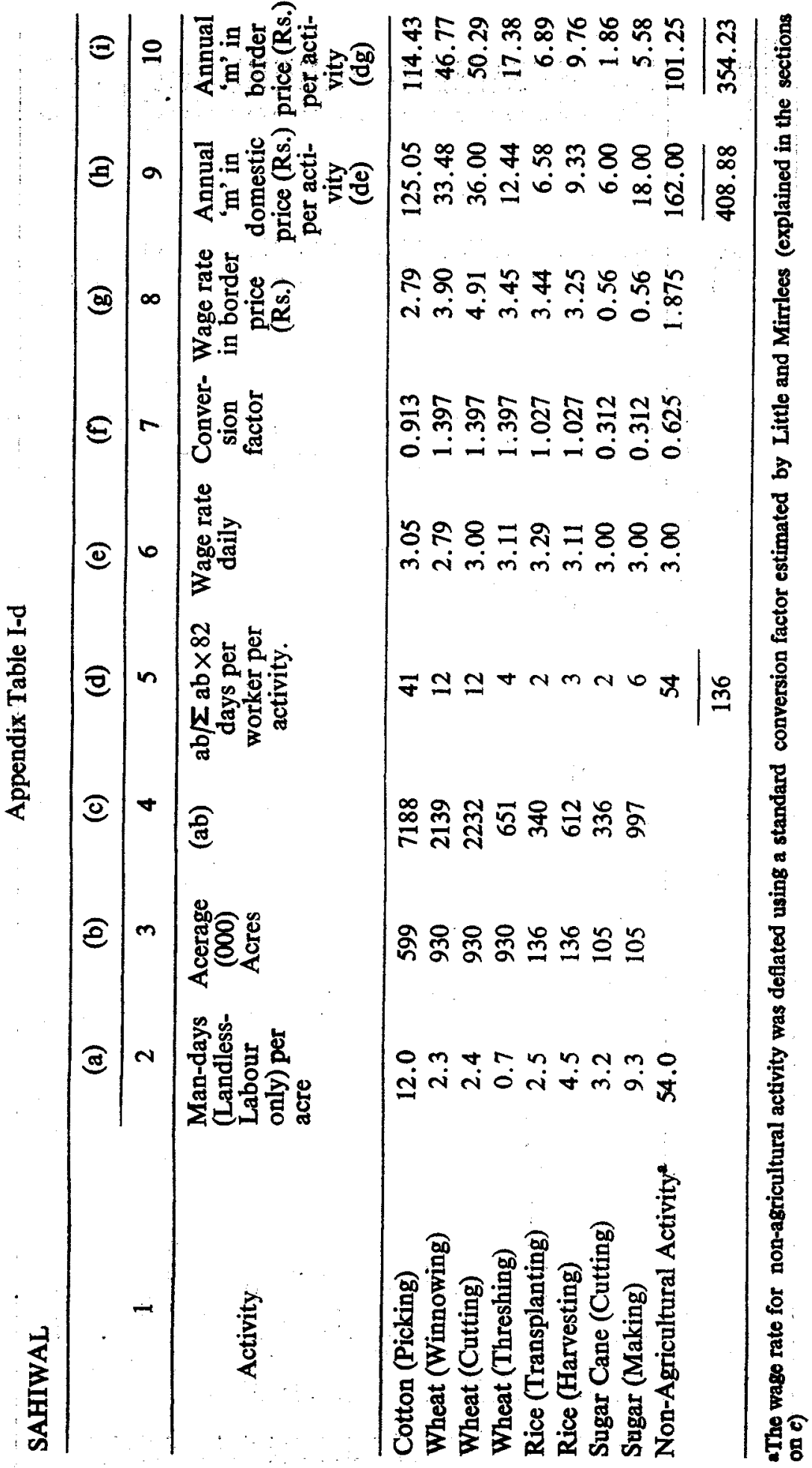




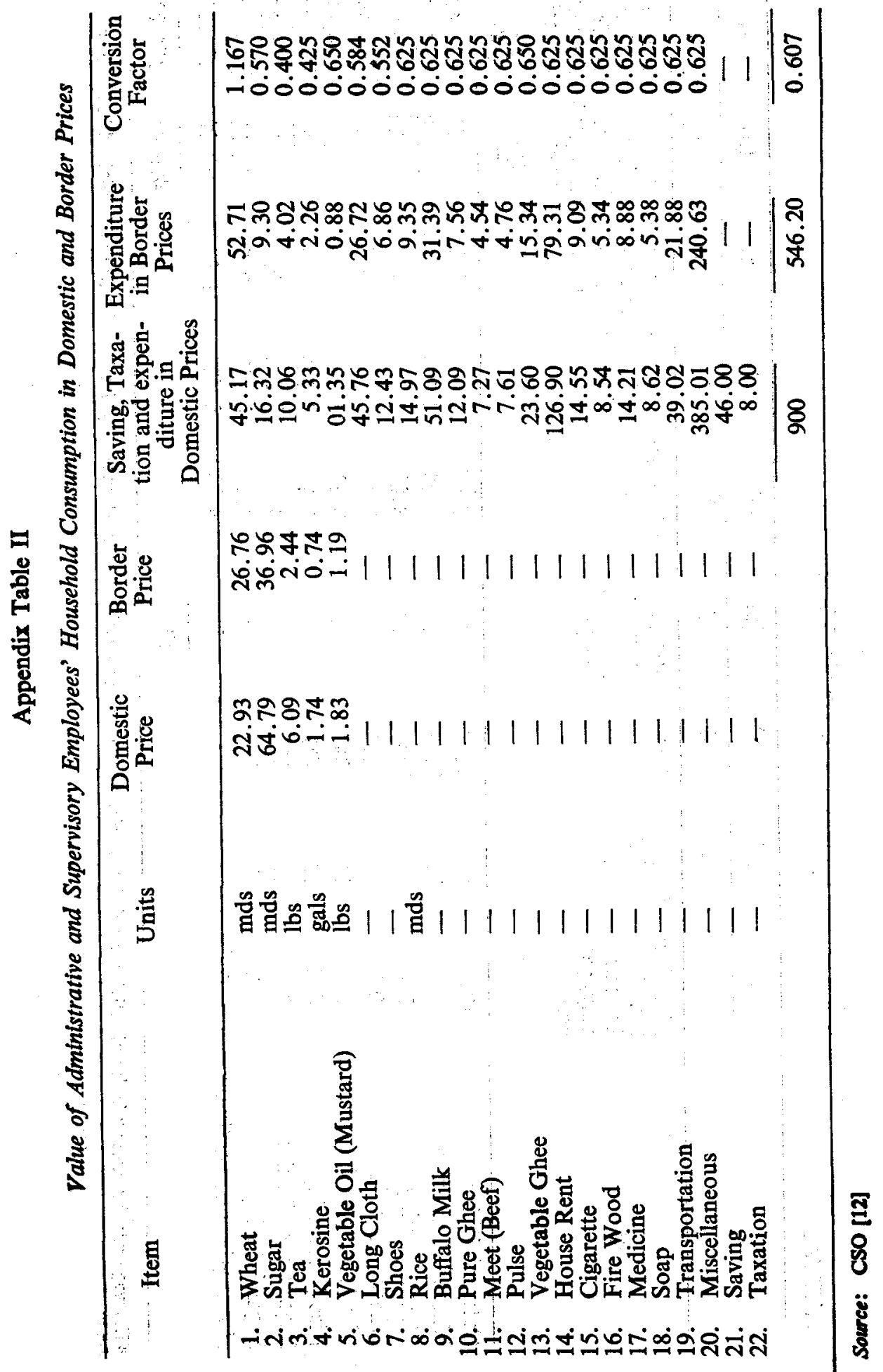




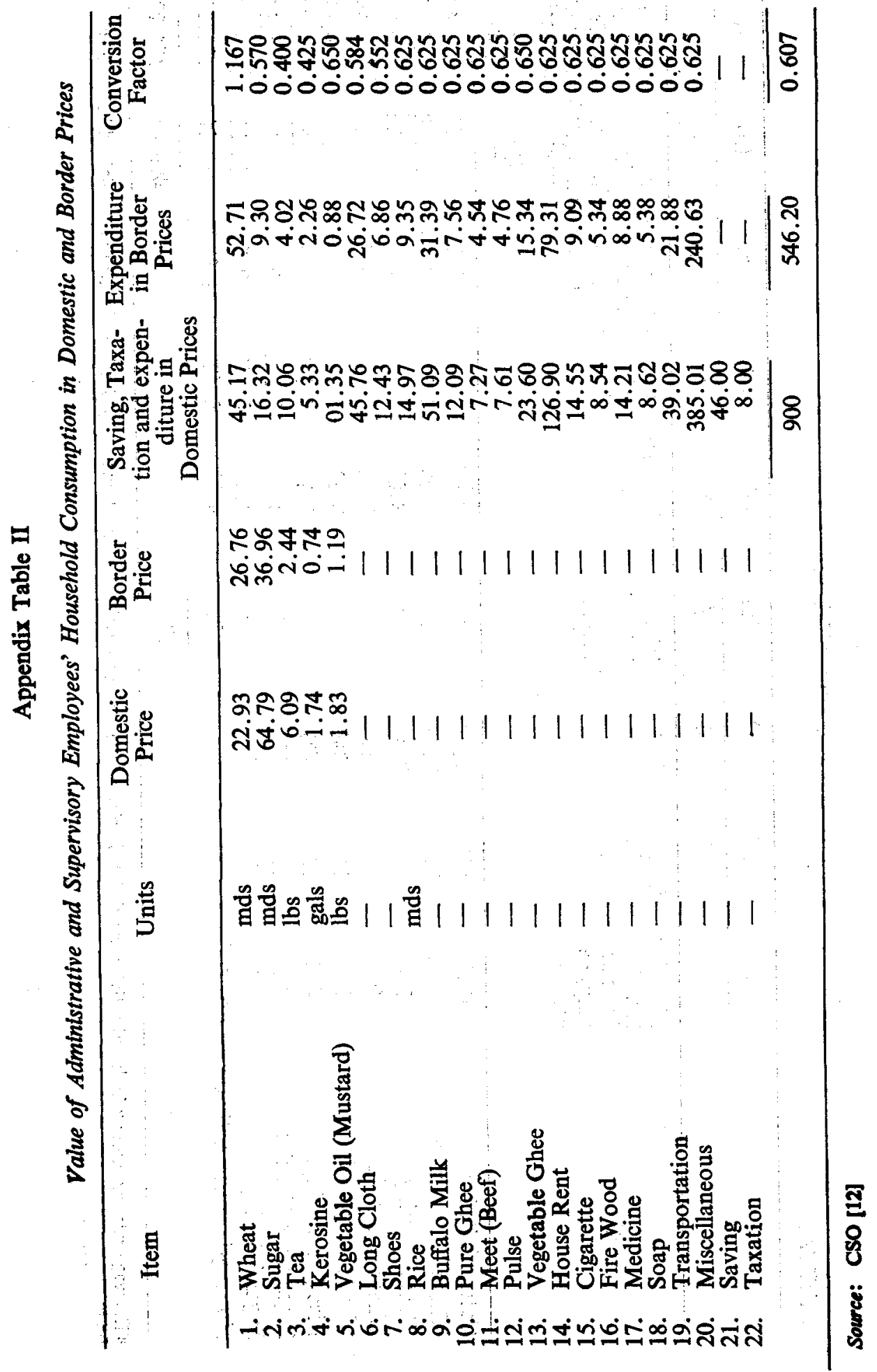




\section{Appendix Table IV}

Social Rate of Return In the Manufacturing Sector

(000 Rs.)

\begin{tabular}{|c|c|c|c|c|}
\hline 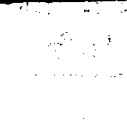 & $\begin{array}{c}a \\
\text { Pomestic } \\
\text { Prices }\end{array}$ & $\begin{array}{c}\mathrm{b} \\
\text { Border } \\
\text { Prices }\end{array}$ & $\stackrel{\text { c }}{\text { Deflator }}$ & $\begin{array}{c}\text { Labour } \\
\text { component }\end{array}$ \\
\hline
\end{tabular}

A. Total Capital

(1) Fixed Assets

$\begin{array}{ll}4,852,949 \quad \begin{array}{l}2,608,727 \\ \text { (a \& c) }\end{array} & -4\end{array}$

(a) Machinery

$3,104,496$

(b) Land and Building

$1,437,263$

(c) Other Fixed Assets

311,190

(2) Accumulated Depreciation

(3) Working Capital $1,030,282$

(4) Total Capital $2,059,131$ $7,942,361 \quad 4,984,411$

B. Production and Revenue

(5) Administrative \& Supervisory

Employees.

(6) Unskilled Workers 140,094

$1,088,727$

(7) Clerical Employees

740,264

106,662

(8) Fuel \& Electricity 389,658

(b)

(9). Other Inputs

29,183

(10) Materials

$6,570,346$

(11). Gross Output - 11,800,523

(12) Indirect Taxation 1,041,680

(13) Gross Output $10,758,843$

(14) Payment to other Factors

304,562

C. Value Added

$$
84,196
$$

$3,70,132$

72,317

.607

.500

.678

$97,415^{\circ}$

D. Social Rate of Return $(r)$
(15) $\mathrm{Cb}-[5 \mathrm{~b}+7 \mathrm{~b}+.45(6 \mathrm{a}) / 4 \mathrm{~b}]$
(16) $\mathrm{Cb}-[5 \mathrm{~b}+7 \mathrm{~b}+.50(6 \mathrm{a}) / 4 \mathrm{~b}]$
15.41
(17) $\mathrm{Cb}-[-5 \mathrm{~b}+7 \mathrm{~b}+.55(6 \mathrm{a}) / 4 \mathrm{~b}]$
14.67
(18) $\mathrm{Cb}-[5 \mathrm{~b}+7 \mathrm{~b}+.60(6 \mathrm{a}) / 4 \mathrm{~b}]$
13.93
(19) $\mathrm{Cb}-[5 \mathrm{~b}+7 \mathrm{~b}+.65(6 \mathrm{a}) / 4 \mathrm{~b}]$
13.18
12.44
(20) $\mathrm{Cb}-[5 \mathrm{~b}+7 \mathrm{~b}+.70(6 \mathrm{a}) / 4 \mathrm{~b}]$
11.70

E. Saving Out of $r$

$$
\mathrm{Cb}-[5 \mathrm{a}+6 \mathrm{a}+7 \mathrm{a}+7 \mathrm{~d} / 4 \mathrm{~b}] \quad 3.48
$$




\section{Notes to Appendix Table IV}

The 1969-70 CMI was used to get most of the data required to compute $K$ and $Y$ Value of Fixed Assets (item I) was reported at its book value and so to get original cost of capital, an estimate of accumulated depreciation had to be added on. Since estimates of the latter were not published in the CMI, an average ratio of accumulated depreciation to Fixed Assets was worked out for the 134 firms whose financial accounts were reported in the Balance Sheet Analysis of Joint Stock Companies [18]. A similar approach was used to compute Working Capital (item 3). Total Capital in domestic prices was revalued at border prices (column (b) ). "Fixed Assets at Original Cost" was subdivided as shown in the table. The domestic values of machinery and plant, and other fixed assets were deflated by the tarriff rate for non-agricultural machinery ${ }^{12}$ The SCF was used to defiate the non-tradeables, land and building. Working Capital in domestic prices was converted similarly into border prices. To compute value added, raw material charges and other inputs (item 8-10) were subtracted from Gross Output at market prices (item 12). Value added at domestic prices was converted into value added at border prices using the ratio between the two estimated by Kemal in Table II of his study [4]. The Social rate of return $r$ was calculated for S.W.R. varying from .45 to .7 of the market wage rate as shown in section $D$. Normally the whole expense incurred on employing administrative, supervisory and clerical staff could be treated as a social cost because these personnel are scarce in developing countries. However, because the value of their consumption in domestic prices is less than the value of this consumption in border prices, their salaries have been deflated by the relevant consumption conversion factors (See Appendix Table II) to get the tradeable value of their consumption.

whe tariff rate was taken from the Customs Import and Export Journal [2]. 


\section{References}

1. Bussink, W.C. 'A Complete Set of Consumption Co-efficient for West Pakistan.' The Pakistan Development Review. Vol. X, No. 2. Summer 1970.

2. Customs Import and Export Journal Vol. XII, Nos. 7 and 8. JulyAugust 1974.

3. Eckert, J.B. 'Rural Labour in the Punjab: A Survey report. Lahore: Planning and Development Department, Government of the Punjab. 1972.

4. Guisinger, S.E. and Irfan, M. 'Real Wages of Industrial Workers in Pakistan: 1954 to 1969-70.' The Pakistan Development Review. Vol. XIII, No. 4, 1974.

5. Harberger, A.C. 'On Measuring Social Opportunity Cost of Labour.' International Labour Review. Vol. 103, No. 6. June 1972.

6. Kemal, A.R. 'The Contribution of Pakistan's Large Scale Manufacturing Industries Towards Gross National Product at World Prices.' The Pakistan Development Review. Vol. XIII, No. 1. Spring 1974.

7. Lal, D. Wells and Welfare. Paris: Development Centre for the OECD. 1972.

8. Lewis, S.R. Jr and Guisinger, S.E. 'Protection in a Developing Country -The Case of Pakistan.' Journal of Political Economy. Vol. 76. November-December 1968.

9. Little, I.M.D. and Mirrlees, J.A. Manual of Industrial Project Analysis in Developing Countries. Vol. 11. Paris: Development Centre of the O.E.C.D. 1968.

10. Little, I.M.D. and Mirrlees, J.A. Project Appraisal and Planning for Development. London: Heinemann Educational Books Ltd. 1974.

11. Naseem, S.M. "A Consistent Series of National Accounts for East and West Pakistan: 1949/50 to 1969/70." (Unpublished paper kindly made available by the author.)

12. Pakistan. Central Statistical Office. Household Income and Expenditure Survey 1970/71. Karachi. 1974.

13. Pakistan. Central Statistical Office. Monthly Bulletin of Statistics for 1970 and 1971. Karachi.

14. Pakistan. Central Statistical Office. Monthly Foreign Trade Statistics of Pakistan, 1970-71. Karachi. 1971.

15. Pakistan. Ministry of Food and Agriculture. Year book of Agricultural Statistics. Supplement, 1972-73. Islamabad. 1974.

16. Punjab. Bureau of Statistics. Development Statistics of the Punjab. Lahore. 1972.

17. Pakistan. Ministry of Finance, Planning and Development. Census of Manufacturing Industries 1968-69. Karachi.

18. State Bank of Pakistan. Balance Sheet of Joint Stock Companies 1966-71. Karachi.

19. United Nations. Food and Agricultural Organization. Trade Yearbook. Rome. 1972. 